внутрішніх справ / В. І. Дяченко // Вісн. Одес. ін-ту внутр. справ. - 1998. - № 4. - С. 179-184. 3. Нещадим М. І. Особливості застосування психологічної діагностики в процесі психологопедагогічного забезпечення підготовки військових фахівців / М. Нещадим // Військова освіта. - 2002. - № 10. - С. 3-14. 4. Освітньо-кваліфікаційна характеристика на випускника Національної академії Державної прикордонної служби України імені Б. Хмельницького / НАДПСУ. - Хмельницький : Вид-во Нац. акад. Держ. прикордон. служби України ім. Б. Хмельницького, 2003. - 36 с. 5. Сарафанюк Е. І. Педагогічні умови підвищення якості загальновійськової підготовки курсантів вищих військових навчальних закладів 3 використанням віртуального моделювання : автореф. дис. на здобуття наукового ступеня канд. пед. наук : спец. 13.00.04 «Теорія і методика професійної освіти» / Е. І. Сарафанюк. - Одеса, 2005. - 22 с. 6. Слєпкань 3. I. Наукові засади педагогічного процесу у вищій школі / 3. І. Слєпкань. - Київ : Вища школа, 2005. - 239 с.

УДК [378.147:016+378.14]:81’25-057.4

Тетяна Бочарникова

\title{
МОЖЛИВОСТІ ПОСДНАННЯ КОМПЕТЕНТНІСНОГО ТА КОНТЕКСТНОГО ПІДХОДІВ У ФАХОВІЙ ПІДГОТОВЦІ МАЙБУТНІХ ПЕРЕКЛАДАЧІВ
}

Бочарникова Т. Ф. Можливості поєднання компетентнісного та контекстного підходів у фаховій підготовці майбутніх перекладачів.

У статті аналізуються можливості поєднання компетентнісного та контекстного підходів у фаховій підготовці майбутніх перекладачів. Вивчається сутність компетентнісного та контекстного підходів. Наголошується на необхідності доповнення компетентнісного підходу контекстним у процесі професійної підготовки студентів, що характеризується максимальним наближенням змісту та форм навчання до змісту i форм професійної діяльності фахівця. Уточнюються поняття «перекладацька діяльність», «професійна компетентність» та «перекладацька компетенція».

Ключові слова: майбутній перекладач, контекстний підхід, професійна компетентність, перекладацька діяльність, навчальна діяльність.

Бочарникова Т. Ф. Возможности объединения компетентностного и контекстного подходов в профессиональной подготовке будущих переводчиков.

В статье анализируются возможности объединения компетентностного и контекстного подходов в профессиональной подготовке будущих переводчиков. Изучается сущность компетентностного и контекстного подходов. Акцентируется внимание на необходимости дополнения компетентностного подхода контекстным в процессе профессиональной подготовки студентов, который характеризуется максимальным приближением содержания и форм обучения к содержанию и формам профессиональной деятельности специалиста. Уточняются понятия «переводческая деятельность», «профессиональная компетентность» и «переводческая компетенция».

Ключевые слова: будущий переводчик, контекстный подход, профессиональная компетентность, переводческая деятельность, учебная деятельность.

Bocharnikova T. F. Professional training of future translators within the framework of the competence-based and contextual approaches. 
The possibilities of combining competence-based and contextual approaches in the training of future translators are analyzed in the article. The essence of competence-based and contextual approaches is studied. It is emphasized the necessity to add contextual approach to competencebased in the course of students' professional training, which is characterized by the maximum approximation of the content and forms of training to the content and forms of professional activity. The concepts of «translation activity», «professional competence» and «translation competence» are given.

Key words: future translator, contextual approach, professional competence, translation activity, learning activity.

Сучасний етап розвитку вищої професійної освіти в Україні та за кордоном характеризується низкою тенденцій, до яких можна віднести неперервність, гуманізацію, модернізацію, інтеграцію й інтенсифікацію. На сьогодні запорукою успішної професійної підготовки майбутніх спеціалістів, безсумнівно, $є$ наслідування зазначених тенденцій. Професійна підготовка спеціаліста - це засвоєння системи знань, умінь, навичок та особистісних якостей, орієнтованих на конкретну фахову діяльність.

Укази Президента України «Про Національну доктрину розвитку освіти» [8] та «Про заходи вдосконалення системи вищої освіти України» [7], Концепція професійної освіти України та Національна Доктрина розвитку освіти в Україні у XXI столітті підкреслюють, що держава несе відповідальність за підготовку кваліфікованих кадрів, здатних до професійного розвитку, опанування та впровадження інноваційних та інформаційнокомунікаційних технологій, конкурентоспроможних на ринку праці.

Результатом процесу професійної підготовки $є$ висококваліфікований, конкурентоспроможний, компетентний спеціаліст, покликаний працювати на рівні міжнародних стандартів, зацікавлений у постійному фаховому зростанні та готовий як до професійної, так і до соціальної мобільності [5].

Підготовку майбутніх перекладачів та формування їхньої професійної компетентності вивчали вітчизняні та зарубіжні науковці: В. Комісаров, Л. Латишев, Р. Міньяр-Белоручєв, В. Сафонова, І. Халєєва та ін. Питання компетентнісного підходу у професійній підготовці сучасних фахівців отримала висвітлення у працях А. Алексюка, І. Беха, Ю. Варданяна, О. Глузмана, І. Зязюна, М. Кадемії, Н. Кузьміної, В. Лугового, В. Петрук та інших науковців.

Ми погоджуємося 3 думкою К. Борсук, яка стверджує, що відсутність єдиного узагальненого підходу до визначення компетентності перекладача може призвести до неспроможності випускника вищого навчального закладу до виживання та стійкої професійної життєдіяльності в умовах сучасного соціально-політичного, ринковоекономічного та інформаційно-комунікаційного простору [1, с. 163-164].

Метою статті є вивчення можливості поєднання компетентнісного та контекстного підходів у фаховій підготовці майбутніх перекладачів.

На нашу думку, головним недоліком традиційної професійної освіти є недостатня орієнтованість на основну мету професійної підготовки. У змісті фахової підготовки перекладачів це виявляється у:

- відсутності специфічного методологічного професійно спрямованого підходу до викладання рідної та іноземної мов;

- надмірній теоретизації дисциплін, що викладаються;

- неузгодженості вимог до обсягу і якості знань, що висуваються до мовних дисциплін та практичних курсів перекладу; 
- недостатньо виражених міждисциплінарних зв'язках.

Указані суперечності традиційної підготовки майбутніх фахівців неодноразово підкреслювалися А. Вербицьким, який уважав, що традиційна модель підготовки спеціаліста, спрямована на засвоєння змісту освіти у вигляді знань, умінь та навичок, не відповідала потребам виховання його професійної особистості $[2 ; 3]$.

Відтак виникає питання щодо підходів до формування професійної компетентності майбутніх перекладачів. На нашу думку, такі підходи повинні орієнтуватися на активізацію навчальної діяльності, підвищення мотивації та практичне оволодіння іноземними мовами у процесі фахової підготовки майбутніх перекладачів.

У випадку підготовки майбутніх перекладачів мета їхньої лінгвістичної підготовки не завжди відповідає вимогам, що висуваються до професійного володіння іноземними мовами, оскільки прагнення до фундаменталізації освіти, до підготовки спеціалістів широкого профілю не завжди враховує лінгвоосвітній потенціал мовної підготовки у фаховому становленні особистості перекладача, формуванні його професійного мислення, збагаченні його мовних практик.

Безсумнівно, осмислення та формування професійно значущих компетенцій повинно здійснюватися на етапі мовного навчання, що передує перекладацькій підготовці та професійній спеціалізації, оскільки володіння такими компетенціями (на рідній та іноземній мові) дозволяє студентам легше оволодіти базовими перекладацькими діями на професійному рівні.

Слід підкреслити, що перекладацьку діяльність ми розуміємо як особливий вид мовленнєвої діяльності, спрямований на реалізацію завдань лінгвістичної комунікації. Професійна компетентність $є$ інтегративною якістю особистості перекладача, що складається 3 лінгвістичної, міжкультурної, психологічної та комунікативної компетенцій та дозволяє перекладачеві на високому рівні виконувати фахову діяльність.

Зазначимо, що поняття «перекладацька компетенція» $є$ предметом дослідження багатьох науковців і розуміється як здатність перекладати (усно або письмово) на професійному рівні. До спеціальних перекладацьких компетенцій належать:

- базова компетенція: знання про переклад, основні поняття перекладознавства;

- дискурсивна компетенція: знання законів побудови дискурсу і його жанрових різновидів в іноземній та рідній мовах;

- спеціальна компетенція: професійна іншомовна комунікативна компетенція сукупність знань, умінь і навичок, що дозволяють на належному рівні здійснювати комунікативну іншомовну діяльність у галузі конкретної професії: специфічні знання та вміння для виконання певного виду професійної діяльності. У формуванні спеціальної компетенції і полягає специфіка цілей даної системи навчання [4, с. 25-28].

Викладання дисциплін на базі компетентнісного підходу змінює звичну стратегію навчання, концентруючи увагу на формуванні професійної мовної особистості майбутніх спеціалістів, на розвитку пізнавальних та професійних мотивів, умінь самостійно оволодівати знаннями, оновлювати та збагачувати їх. Отже, формування специфічних компетенцій, що відіграють роль основних компонентів професійного мислення, стає обов'язковим першим щаблем становлення професійної компетентності як здатності ефективно здійснювати професійну діяльність.

3 огляду на викладене вище метою професійної лінгвістичної підготовки визначємо навчання студентів стратегіям засвоєння іноземних мов, методологічним основам текстової діяльності, професійно значущим діям на рідній та іноземній мовах, тобто умінню 
встановлювати певні міждисциплінарні зв'язки.

Завдяки цьому змінюються й освітні цілі студентів- майбутніх перекладачів: вивчаючи іноземні мови, не тільки оволодіти лінгвістичною компетенцією, але й навчитися сприймати та утримувати в пам'яті зміст повідомлення, виокремлювати його змістовні одиниці, поєднувати їх у більш об'ємні інформативні блоки, формулювати та перефразовувати зміст повідомлень, усвідомлювати та зберігати при відтворенні змісту типову та жанрову специфіку тексту, адекватно інтерпретувати зміст мовної та немовної поведінки представників іншомовної культури, орієнтуватися в соціокультурному контексті конкретної комунікативної ситуації.

Саме в цьому, на нашу думку, полягає специфіка формування професійного володіння мовою. Основою професійної мовної особистості стає розвиток іiі інтелектуальних якостей. А мовленнєвий досвід збагачується у такому випадку професійно значущими компетенціями (семантичною, інтерпретативною, текстовою та міжкультурною) як у рідній мові, так і в іноземних. Виходячи із зазначеного, уважаємо, що орієнтація на розв'язання комунікативних та квазіпрофесійних завдань допомагають студентам осмислено готуватися до оволодіння перекладацькою професією. Спираючись на розвиток професійно значущих компетенцій, міждисциплінарна дидактична система забезпечує координацію мовних дисциплін зі спеціальними перекладацькими предметами.

Перехід на нові стандарти дає студентам більше можливостей для самостійного вибудовування освітньої траєкторії відповідно до своїх задатків, здібностей та можливостей. У такому випадку посилюється роль викладача в уточненні цілей та плануванні навчальної діяльності.

Водночас перехід на дворівневу систему («бакалавр - магістр») виявив більш складні завдання - забезпечити професійну мовну та перекладацьку підготовку студентів за чотири роки. Беручи до уваги той факт, що у студентів-вступників на перекладацькі факультети здібності до перекладацької діяльності не завжди сформовані, виявляються більш серйозні суперечності: традиційні методи професійної підготовки майбутніх перекладачів не можуть забезпечити ефективну перекладацьку підготовку за такий короткий термін. 3 одного боку, нові вимоги до вищої освіти передбачають переоцінку підходів до самостійної роботи та посилення ролі професійно спрямованих інтерактивних форм проведення занять. 3 іншого боку, ці вимоги, розроблені на основі компетентнісного підходу, передбачають отримання кінцевого результату навчання у вигляді набору знань, умінь та навичок, доведених до рівня компетенції, формуючих здатність самостійно застосовувати їх у практичних ситуаціях професійної діяльності. Проте виникає логічне запитання: у який спосіб довести знання та вміння до рівня компетенцій?

Так, на нашу думку, у межах підготовки професійних перекладачів як посередників у міжкультурній комунікації необхідною $є$ інтеграція теорії контекстного навчання та методології компетентнісного, міжкультурного та когнітивно-комунікативного підходів, на основі яких і мають розроблятися дидактичні матеріали.

Відтак особливого значення в системі підготовки професійних перекладачів набуває, фаза орієнтації в майбутній професії [6, с. 66-76], спрямована на:

- розуміння специфіки та основних функцій професійної діяльності;

- усвідомлення психологічних, комунікативних, особистісних вимог, що висуваються до професії;

- виявлення професійно значущих інтелектуальних, мовленнєвих та особистісних якостей, їх розвиток та удосконалення у процесі навчання; 
- розуміння відповідальності за вибір професії та за процес ії набуття.

Важливо, щоб абітурієнти, обираючи професію перекладача, добре уявляли собі вимоги до цієї професії та порівнювали з ними свої здібності й можливості: щоб до вступу на перекладацький факультет вони могли сформулювати не тільки те, «щцо» вони зобов’язані знати і вміти, але й те «як» знати, щоб опанувати обрану професію.

Так, на факультеті «Референт-перекладач» Харківського гуманітарного університету «Народна українська академія» організовано низку заходів, що сприяють створенню відповідного освітнього середовища, 3-поміж яких можна виокремити зустрічі 3 перекладачами-практиками, відкриті заняття з перекладу та мовних дисциплін. На заняттях викладачі мовних дисциплін активно використовують завдання на перефразування, розігрування та моделювання професійних ситуацій, що вимагають знання культури країн, мови яких вивчаються, та володіння мовленнєвим етикетом рідною мовою. Такі види робіт, безсумнівно, сприяють тому, що: майбутні перекладачі змінюють пасивну роль на роль активного учасника навчального процесу, оскільки мають доводити та відстоювати власну позицію, вибудовувати комунікацію в групі; аналіз кожної конкретної ситуації дозволяє закріплювати навички усної та письмової комунікації, використовувати іноземну мову як інструмент для розв'язання поставлених завдань тощо.

На молодших курсах створенню професійного освітнього середовища сприяють численні професійно спрямовані свята, ігри та конкурси (фонетичний, орфографічний, лінгвокраїнознавчий, театральний, Тижні іноземних мов і культур, День перекладача, різноманітні прес-конференції, засідання Євроклубу).

Для студентів старших курсів проводяться імітаційно-ділові ігри, у яких активну участь беруть носії іноземних мов. Зазначений тип навчання поєднує елементи рольових, імітаційних та ділових ігор, дозволяє імітувати всі аспекти перекладацької діяльності, завдяки чому стає можливим скорочення часу накопичення професійного досвіду, формування у майбутніх фахівців цілісного уявлення про професію перекладача.

Вивчення можливостей поєднання компетентнісного та контекстного підходів у фаховій підготовці майбутніх перекладачів надало змогу зробити висновок про необхідність інтеграції теорії контекстного навчання та методології компетентнісного, на основі яких i мають розроблятися та удосконалюватися форми професійної підготовки майбутніх перекладачів. Перспективним уважаємо подальше вивчення можливостей контекстного підходу у фаховій підготовці майбутніх філологів та перекладачів.

\section{Література}

1. Борсук К. М. Порівняльний аналіз підходів до визначення професійної компетентності сучасного перекладача / К. М. Борсук // Порівняльна професійна педагогіка. - 2013. - №1. - С. 163-173. 2. Вербицкий А. А. Активное обучение в высшей школе: контекстный подход / А. А. Вербицкий. - Москва : Высшая школа, 1991. - 207 с. 3. Вербицкий А. А. Компетентностный подход и теория контекстного обучения: [материалы к четвертому заседанию методологического семинара 16 ноября 2004 г.] / А. А. Вербицкий Москва : Исследовательский центр проблем качества подготовки специалистов, 2004. - 84 с. 4. Гавриленко Н. Н. Теория и методика обучения переводу в сфере профессиональной коммуникации / Н. Н. Гавриленко. - Москва: Научно-техническое общество имени академика С. И. Вавилова, 2009. - 178 с. 5. Лунев А. Н., Социальная практика как философское основание педагогического стратегирования в техническом вузе / А. Н. Лунев, Н. Б. Пугачева // Общество: философия, история, культура. - 2013. - № 4. - С. 34-37. 6. Поршнева Е. Р. Роль профессиональной ориентации в повышении эффективности 
обучения переводчиков-профессионалов / Е. Р. Поршнева // Психологическая наука и образование. - 2003. - № 1. - С.26-32. 7. Указ Президента України «Про заходи вдосконалення системи вищої освіти України»/ Міністерство освіти і науки України.№ 199/2004, 17.02. - Київ, 2004 8. Указ Президента України «Про Національну доктрину розвитку освіти» / Міністерство освіти і науки України. - №347/2002, 17.04. - Київ, 2002.

Юлія Лаптінова

\section{ФОРМУВАННЯ ІНШОМОВНОЇ КОМУНІКАТИВНОЇ КОМПЕТЕНТНОСТІ МАЙБУТНІХ МУЗИКАНТІВ-ВИКОНАВЦІВ У ПРОЦЕСІ НАВЧАННЯ АНГЛІЙСЬКОГО ДІАЛОГІЧНОГО МОВЛЕННЯ}

Лаптінова Ю. І. Формування іншомовної комунікативної компетентності майбутніх музикантів-виконавців у процесі навчання англійського діалогічного мовлення.

У статті запропоновано подальше розроблення теоретико-методичної концепції формування іншомовної комунікативної компетентності майбутніх фахівців у навчальному процесі вищого навчального закладу. 3'ясовано труднощі викладання іноземної мови на немовних спеціальностях 3 урахуванням специфіки музично-виконавської професійної діяльності. Розглянуто специфічні особливості діалогу як засобу становлення комунікативної компетентності майбутніх музикантів-виконавців. Запропоновано комплекс спеціальних вправ, на основі якого можна створити оптимальні умови для формування діалогічних умінь студентів.

Ключові слова: комунікативна компетентність, діалогічне мовлення, непрофілююча спеціальність, фахова підготовка.

Лаптинова Ю. И. Формирование иноязычной коммуникативной компетентности будущих музыкантов-исполнителей в процессе обучения английской диалогической речи.

В статье предложена дальнейшую разработку теоретико-методической концепции формирования иноязычной коммуникативной компетентности будущих специалистов в учебном процессе высшего учебного заведения. Выявлены сложности преподавания иностранного языка на неязыковых специальностях с учетом специфики музыкальноисполнительской профессиональной деятельности. Рассмотрены специфические особенности диалога как средства становления коммуникативной компетентности будущих музыкантов-исполнителей. Предложен комплекс специальных упражнений, на основе которого можно создать оптимальные условия для формирования диалогических умений студентов.

Ключевые слова: коммуникативная компетентность, диалогическая речь, непрофилирующая специальность, профессиональная подготовка.

Laptinova Yu. I. The formation of foreign language communicative competence of future musicians in teaching English dialogical speech.

The article suggests the further development of theoretical and methodological concept of foreign language communicative competence formation of future professionals in the educational process of universities.

There was revealed the complexity in teaching Foreign Language for students of nonlanguage specialties taking into account the specificity of musicians' professional activities. 